\title{
Pengaruh Pemberian Mikoriza dan Konsentrasi Pupuk Organik Cair Limbah Kulit Pisang terhadap Pertumbuhan Bibit Kopi Arabika (Coffea arabica L.) Varietas Ateng Keumala
}

\section{The Influence Of Mycorrhiza and Concentration Liquid Organic fertilizer Banana Skin Waste On Growth Coffea Breed Arabika (Coffea arabica L.) Variety Of Ateng Keumala}

\author{
Irawati $^{1}$, Erita Hayati ${ }^{1}$, Ashabul Anhar ${ }^{1 *}$ \\ ${ }^{1}$ Jurusan Agroteknologi, Fakultas Pertanian, Universitas Syiah Kuala
}

\begin{abstract}
Abstrak. Penelitian ini bertujuan untuk mengetahui pengaruh pemberian mikoriza dan konsentrasi pupuk organik cair dari limbah kulit pisang terhadap pertumbuhan bibit kopi arabika varietas Ateng Keumala. Penelitian ini dilaksanakan di lahan perkebunan kopi milik petani di kampung Beranun Kecamatan Bandar Kabupaten Bener Meriah dari bulan Juni sampai September 2018. Penelitian ini menggunakan Rancangan Acak Kelompok (RAK) pola faktorial $2 \times 4$ dengan 3 ulangan, sehingga terdapat 24 satuan percobaan dan uji $\mathrm{F}$ yang signifikan dilanjutkan dengan uji beda nyata jujur taraf $5 \%$. Faktor pertama adalah pemberian mikoriza dengan 2 taraf yaitu kontrol (M0) dan 10 g/tanaman (M1). Faktor kedua adalah konsentrasi pupuk organik cair limbah kulit pisang dengan 4 taraf yaitu kontrol, $2 \%, 4 \%$ dan $6 \% \mathrm{ml} / \mathrm{L}$. Parameter yang diamati adalah tinggi tanaman, jumlah daun, diameter pangkal batang, panjang akar, berat berangkasan basah, dan berat berangkasan kering. Hasil penelitian menunjukan bahwa, pemberian mikoriza tidak berpengaruh nyata terhadap semua parameter yang diamati. Konsentrasi pupuk organik cair berpengaruh nyata terhadap parameter tinggi tanaman umur 60 HSPT, namun tidak berpengaruh nyata terhadap parameter tinggi tanaman, jumlah daun, diameter pangkal batang, panjang akar, berat berangkasan basah, dan berat berangkasan kering. Perlakuan terbaik di jumpai pada konsentrasi pupuk organik cair limbah kulit pisang $4 \% \mathrm{ml} / \mathrm{L}$. Terdapat interaksi yang nyata pada jumlah daun umur 30 HSPT.
\end{abstract}

Kata kunci: Kopi arabika, Limbah kulit pisang, Mikoriza, Pupuk organik cair.

Abstract. Research this aims for knowing influence gift mycorrhiza and concentration fertilizer organic liquid from waste skin banana to growth arabica coffee seeds varieties Ateng Keumala. Research this on account, right in land coffee plantation owned the farmer in village Brave District of Bandar District Right Festive of the month June until September 2018. This research uses Design Random Group (RAK) pattern factorial $2 \times 4$ with 3 replications, so that there are 24 experimental units and continued with an honest real difference test of $5 \%$ level in a significant $\mathrm{F}$ test. Factor first is it gift mycorrhiza with 2 levels that is control (M0) and $10 \mathrm{~g} / \mathrm{plant}$ (M1). The second factor is concentration fertilizer organic liquid waste skin banana with 4 levels namely control, $2 \%, 4 \%$ and $6 \% \mathrm{ml} / \mathrm{L}$. Parameter observed is high plant height, amount leaf, stem diameter, root length, wet weight, and dry weight. Results research showing that, the administration of mycorrhizae did not significantly affect all observed parameters. The concentration of liquid organic fertilizer had a significant effect on the parameters of plant age 60 diafter day transflanting, but did not significantly affect the parameters of plant height, number of leaves, stem base diameter, root length, wet weight, and dry weight. The best treatment was found at a concentration of $4 \% \mathrm{ml} / \mathrm{L}$ of banana peel liquid organic fertilizer. There were significant interactions on the number of leaves aged 30 diafter day transflanting.

Keyword : Arabica coffee, Banana skin waste, Mycorrhiza, Liquid Organik Fertilizer

Corresponding author: Ashabul. anhar@unsyiah.ac.id

Jurnal Ilmiah Mahasiswa Pertanian - AGT, Vol. 4, No. 2, Mei 2019: 21-30 


\section{PENDAHULUAN}

Kopi merupakan komoditas rakyat yang telah begitu lama dibudidayakan, konsumsi dunia secara keseluruhan berasal dari spesies kopi arabika (70\%), spesies kopi robusta $(26 \%)$ dan spesies kopi liberika (4\%). Penghasil kopi arabika di Indonesia yaitu di provinsi Aceh dengan pusat pengembangannya terletak di daerah dataran tinggi Gayo, yaitu terletak di Kabupaten Aceh Tengah dan Bener Meriah. Tanaman kopi merupakan komoditas unggulan pertanian di Kabupaten Bener Meriah pada sektor perkebunan. Jumlah produksi tahun 2016 sebanyak 15.980,07 ton dengan luas tanam 42.664,84 ha (BPS, 2016).

Permasalahan yang dihadapi petani kopi dataran tinggi Gayo yaitu mutu kopi arabika dan produktivitas yang dihasilkan masih rendah. Dengan demikian pemerintah mengeluarkan kebijakan kopi nasional dibidang budidaya kopi. Upaya yang dilakukan oleh pemerintah adalah $\mathrm{m}$ e $\mathrm{ng}$ optimalisasikan penggunaan bibit yang sesuai kondisi agroklimat tempat penanaman (Retno, 1999).Untuk mendapatkan keberhasilan dalam budidaya kopi salah satunya perlu dilakukan pemilihan bibit tanaman yang unggul serta memerlukan media tanam yang baik seperti memiliki sifat biologi tanah, fisika tanah dan kimia tanah yang bagus sehingga dapat mendukung pertumbuhan dan perkembangan bibit tanaman kopi. Medium pembibitan yg sering digunakan adalah lapisan top soil dengan campuran pupuk organik sehingga diperoleh media yang baik (Nurhakim et.al., 2014). Terlebih apabila tanaman kopi yang ditanam pada Andisol, Usaha untuk meningkatkan ketersediaan unsur hara $\mathrm{P}$ bisa dilakukn dengn memberikan amelioran (seperti gamal, jerami padi dan pupuk kandang) serta pemberian mikoriza pada jenis tanah Andisol (Karnilawati et al., 2013).

Mikoriza merupakan jamur yang dapat bersimbiosis dengan akar dan dapat memperkuat sistem perakaran tanaman dalam menyerap unsur hara dan air. Ada beberapa manfaat mikoriza bagi tanaman yaitu meningkatkan hormon pertumbuhan, mencegah infeksi patogen yang menyerang akar, dan meningkatkan abrorbsi hara dari dalam tanah (Mahdi, 2012; Majid, 2009). Penggunaan mikoriza di dalam pembibitan tanaman kopi dapat merupakan suatu cara yang mampu mendukung pertumbuhan kopi yang sehat dan kuat dengan demikian tanaman kopi dapat tumbuh dengan baik di lahan pertanian (Andrad et al., 2009).

Nasrullah et al., (2015) dalam hasil penelitiannya menyatakan bahwa perlakuan pemberian takaran mikoriza yang paling baik adalah $10 \mathrm{~g}$ /tanaman pada bibit kakao (Theobroma cacao L). Sejalan dengan hasil penelitiian Djodi, et al., (2013) menunjukan bahwa pemberian mikoriza $10 \mathrm{~g}$ dan $20 \mathrm{~g} \mathrm{polibag}^{-1}$ nyata dapat meningkatkan tinggi bibit kopi umur 84 HSP, diameter batang pada umur 84 HSP dan 112 HSP, serta berat kering bibit umur 112 HSP.

Pemupukan yaitu pemberian bahan organik maupun anorganik untuk menyediakan hara bagi tanaman melalui tanah dan di serap oleh akar tanaman, selain itu juga dapat membantu memperbaiki kesuburan tanah serta mampu meningkatkan pertmbuhan dan pekembangan tanaman supaya tanaman mampu meningkatkan produksi yang optimal (Nyakpa et al., 1998). Menurut Pranata (2004) pupvp organik adalah pupvk yang didapatkan dari makhluk hidup yang telah mengalami proses pelapukan, juga dapat berasal dari sisa tumbuhan ataupun dari limbah rumah tangga.

Menurut Santi dan Guenadi (2008) pupuk organik cair lebih efektif dibandingkan dengan pupuk organik padat, karena penggunaan pupuk organik cair memiliki beberapa 
kelebihan yaitu pengaplikasiannya lebih mudah, kandungan unsur hara dalam pupuk cair lebih mudah untuk diserap oleh tanaman, mikroorganisme dalam pupuk organik cair lebih banyak, mampu mengatasi defesiensi hara, tidak mudah terjadi pencucian hara, mampu menyediakan hara secara cepat, proses pembuatannya memerlukan waktu yang lebih cepat, serta penggunaannya mudah dilakukan yakni dengan cara disemprotkan ke tanaman (Siboro dan Herlina, 2013).

Kulit pisang adalah limbah rumah tangga yang dapat digunakan sebagai bahan pembuatan pupuk organik cair. Kulit pisang mengandung banyak unsur hara yang dibutuhkan tanaman salah satunya yaitu unsur nitrogen (Hakim, 2009). Menurut (Fadhlan et al., 2015) Perlakuan pupuk organik cair pada konsentrasi $20 \mathrm{ml} / 1$ air berpengaruh nyata terhadap tinggi tanaman pada 6-12 (Minggu setelah pindah tanam), diameter batang 8-12 (minggu setelah pindah tanam), berat kering tajuk, berat kering akar dan volume akar pada bibit kopi robusta.

Menurut hasil penelitian (Nasution et al., 2014). menyatakan bahwa kandungan unsur hara yang terdapat pada pupuk organik cair limbah kulit pisang kepok yakni, COrganik 0,55\%, N-Total 0,18\%, P2O5 0,043\%, K20 1,137\%, C/N 3,06\% dan Ph 4,5. Menurut (Priangga et al., 2013) pupuk organik cair limbah kulit pisang pada konsentrasi $40 \mathrm{ml} / 1$ air berpengaruh nyata tehadap pertumbuhan tanaman kangkung darat (Ipomea reptana poir).

\section{BAHAN DAN METODOLOGI PENELITIAN}

Penelitian dilaksanakan di lahan perkebunan kopi petani di kampung Beranun Kecamatan Bandar Kabupaten Bener Meriah dan Laboratorium Fisiologi Tumbuhan Fakultas Pertanian Universitas Syiah Kuala Darussalam Banda Aceh, yang berlangsung dari bulan Juni sampai September 2018.

Alat-alat yang digunakan dalam penelitian ini adalah timbangan analitik, jangka sorong, gelas ukur $500 \mathrm{ml}$, lesung, ayakan, meteran, wadah pembuatan pupuk organik cair, pisau, cangkul, gembor, oven, pisau silet, kamera, gunting. Bahan yang digunakan yaitu berupa bibit kopi arabika varietas ateng keumala umur 1 bulan, tanah, mikoriza, pupuk organik cair, air, tali rapia, polibag, dan naungan.

\section{Persiapan Lahan}

Lahan dipersiapkan sebagai tempat untuk meletakkan polybag bibit tanaman kopi pada saat penelitian dan dibuat paranet ukuran 7 meter $\times$ lebar 5 meter dengan tinggi 5 meter.

\section{Pembuatan Naungan}

Pembuatan naungan sangat penting dilakukan pada area pembibitan tanaman kopi untuk mengurangi sinar matahari. Naungan dibuat dengan menggunakan bambu sebagai tiang dan paranet sebagai atap dengan tinggi $120 \times 90 \mathrm{~cm}$.

\section{Persiapan Media Tanam Tumbuhan Kopi}

Media tanam untuk tanaman kopi adalah tanaah lapisan atas (top soil) jenis Andisol diambil dari tanah perkebunan milik petani di Kampung Beranun Bener Meriah. Media tanah yang telaah diayak dimsukkan ke dalam polibag volume $3 \mathrm{~kg}$ untuk ditanami bibit kopi. 


\section{Pemindahan Bibit ke Media Tanam}

Bibit kopi yang sudah berumur 1 bulan diperoleh dari salah satu kebun pembibitan kopi milik petani di Kampung Pondok Ulung Kecamatan Bandar Kabupaten Bener Meriah, kemudian dipindahkah ke dalam polibag penelitian dengan cara polibag awal di gunting tinggalkan sebagian tanah dan masukkan bibit ke dalam polibag volume $3 \mathrm{~kg}$.

\section{Pembuatan pupuk organik cair limbah kulit pisang}

Pupuk organik cair limbah kulit pisang dibuat dengan cara menyiapkan kulit pisang yang matang, kemudian dicincang kecil-kecil, lalu di timbang sebanyak $5 \mathrm{~kg}$ selanjutnya kulit pisang di tumbuk sampai halus berair. Hasil tumbukan kulit pisang di masukkan kedalam wadah lalu dicampurkan dengan air sebanyak $5000 \mathrm{ml}$, aduk sampai rata dan ditutup rapat, Fermentasi dilakukan selama 8 hari (Rambitan dan Sari, 2013) kemudian melakukan penyaringan, selanjutnya dimasukkan ke dalam botol aqua.

\section{Aplikasi Mikoriza pada Tanaman Kopi}

Mikoriza diberikan pada saat bibit kopi dipindahkan ke dalam polibag volume $3 \mathrm{~kg}$, yaitu 0 dan $10 \mathrm{~g} /$ tanaman pada kedalaman $10 \mathrm{~cm}$ lubang tanam.

\section{Pengaplikasian pupuk organik cair limbah kulit pisang pada tanaman kopi}

Pengaplikasian Pupuk organik cair limbah kulit pisang diberikan dengan cara disiram di pangkal batang bibit tanaman kopi dilakukan pada 2 minggu setelah pindah tanam (MSPT) dan diakhiri pada 10 MSPT. Proses Pemupukan ini diberikan dengan cara mengencerkan pupuk organik cair limbah kulit pisang dengan mengukur konsentrasi yang telah ditentukan yaitu kontrol, 2\%, 4\%, 6\% menggunakan gelas ukur. Pemupukan ini dilakukan setiap 2 minggu sekali dengan total pemberian 5 kali selama 3 bulan.

\section{Pemeliharaan tanaman}

Pemeliharaan tanaman bibit kopi yaitu melakukan penyiraman yaitu paagi dan sore hari dan disesuaikan dengan kondiisi cuaca. Pencabutan gulma dilakukan dengan cara manual yaitu mencabut gulma Liar Kuning (Galinsoga quadriradiata) yang tumbuh dalam polibag. Pengendalian hama dilakukan secara manual dengan mengambil dan membuang hama Belalang (Valanga nigricornis), siput (Milax gagates) yang terdapat diareal penelitian.

\section{Parameter Pengamatan}

Ada beberapa parameter pengamatan yakni :

\section{a. Tinggi tanaman (cm)}

Parameter tinggi tanaman di amati pada umur 30, 60, dan 90 (HSPT) pada fase pembibitan di ukur mulai dari pangkal batang yang ditandai dengan ujung daun tertinggi penggaris.

\section{b. Jumlah daun (helai)}

Jumlah daun dihiitung berdasrkan bayaknya jumlah daun bibit kopi yang sudah mmbuka sempurna, dihitung secara manual diamati pada umur 30, 60 daan 9o (HSPT). 


\section{c. Diameter pangkal batang ( $\mathrm{mm})$}

Diameter pangkal batang diukur dengan alat jangka sorong pada umur 90 hari setelah pindah tanam (HSPT) pada bibit kopi.

\section{d. Panjang Akar (cm)}

Panjang akar diukur darri pangkal batang hingga ujung akar dengan mistar pada bibit kopi umur 90 (HSPT).

\section{e. Berat berangkasan basah (g)}

Berangkasan Basah bibit tanaman kopi ditimbang dengan menggunakan timbangan analitik dilakukan setelah bibit kopi dibongkar dari polibag pada akhir pengamatan (90 HSPT). Berangkasan basah meliputi daun, batang dan akar setelah dibersihkan dari media tanam.

\section{f. Berat berangkasan kering (g)}

Berangkasan kering bibit tanaman kopi ditimbang dengan menggunakan timbangan analitik, setelah berangkasan basah bibit kopi mngeringkannya dengan memasukkan ke dalam oven dengan suhuu $60^{\circ} \mathrm{C}$ dgn menggunakan waktu selama $2 \times 24$ jam.

\section{HASIL DAN PEMBAHASAN}

\section{Hasil penelitian \\ Pengaruh Pemberian Mikoriza terhadap Pertumbuhan Bibit Kopi}

Berdasarkan hasil penelitian memperlihatkan bahwa pemberian mikoriza tidak berpengaruh nyata terhadap semua parameter (tinggi tanaman, jumlah daun, diameter pangkal batang, panjang akar, berat berangkasan basah dan berat berangkasan kering) pada umur 30, 60 dan 90 HSPT.

\section{Pengaruh konsentrasi pupuk organik cair limbah kulit pisang terhadap pertumbuhan bibit kopi.}

Berdasarkan hasil analisis ragam menunjukan bahwa perlakuan konsentrasi pupuk organik cair limbah kulit pisang berpengaruh nyata terhadap parameter tinggi tanaman umur 60 HSPT, namun tidak berpengaruh nyata pada umur 30 dan 90 HSPT. Selanjutnya tidak berpengaruh nyata terhadap beberapa parameter lainnya (jumlah daun, diameter pangkal batang, panjang akar, berat berangkasan basah dan berat berangkasan kering) pertumbuhan bibit kopi umur 30, 60 dan 90 HSPT.

Hasil Uji F pd analisis ragam konsentrasi pupuk organik cair limbah kulit pisang berpengaruh nyata terhadap parameter tinggi tanaman bibit kopi umur 60 HSPT, namun tidak berpengaruh nyata pada umur 30 dan 90 HSPT. Rata-rata tinggi tanaman bibit kopi pada pelakuan konsentrasi pupuk organik cair limbah kulit pisang dapat dilihat pada Tabel 1. 


\section{Tinggi tanaman (cm)}

Tabel 1. Rata-rata tinggi tanaman perlakuan konsentrasi pupuk organik cair limbah kulit pisang terhadap bibit kopi umur 30,60 dan 90 HSPT.

\begin{tabular}{llll}
\hline \multirow{2}{*}{ Konsentrasi } & \multicolumn{3}{c}{ Tinggi Tanaman (cm) } \\
\cline { 2 - 4 } & 30 HSPT & 60 HSPT & 90 HSPT \\
\hline Kontrol (P0) & 12,43 & $13,59 \mathrm{ab}$ & 14,46 \\
$\mathbf{2 \%}$ (P1) & 12,61 & $13,07 \mathrm{a}$ & 14,13 \\
$\mathbf{4 \%}$ (P2) & 13,06 & $14,22 \mathrm{~b}$ & 15,15 \\
$\mathbf{6 \%}$ (P3) & 12,55 & $13,44 \mathrm{a}$ & 14,18 \\
\hline BNT (0,05) & & $\mathbf{0 , 9 6}$
\end{tabular}

Keterangan : Angka yg diikuti oleh huruf yang sama pada kolom yg sama berbeda nyata berdasarkan uji Beda Nyata Terkecil (BNT) pada taraf $\alpha=0,05$.

Tabel 1. Menunjukan bahwa pada tinggi tanaman bibit kopi, perlakuan terbaik dijumpai pada pengamatan tinggi tanaman umur 60 HSPT yaitu 14,22 dengan konsentrasi pupuk organik cair limbah kulit pisang (P2) 4\%.

Hasil Uji F memperlihatkan bahwa terdapat intraksi yang nyata antara mikoriza dan konsentrasi pupuk organik cair limbah kulit pisang tehadap pertumbuhan bibit kopi pada parameter jumlah daun 30 HSPT.

\section{Interaksi pemberian mikoriza dan konsentrasi pupuk organik cair limbah kulit pisang terhadap Pertumbuhan Bibit Kopi}

\section{Jumlah daun (Helai)}

Hasil uji $\mathrm{F}$ pada analisis ragam menunjukan bahwa interaksi yang nyata antara mikoriza dan konsentrasi pupuk organik cair limbah kulit pisang terhadap Pertumbuhan Bibit Kopi pada jumlah daun 30 HSPT. dapat dilihat pada Tabel 2.

Tabel 2. Rataa-rata pertambahan jumlah daun bibit kopi akibat perlakuan antara mikoriza dan konseentrasi pupuk organik cair limbah kulit pisang terhadap Pertumbuhan Bibit Kopi umur 30 HSPT.

Perlakuan Konsentrasi POC limbah kulit pisang

\begin{tabular}{lllll}
\hline & $\mathbf{P}_{\mathbf{0}}$ (Kontrol) & $\mathbf{P}_{\mathbf{1}}(\mathbf{2 \%})$ & $\mathbf{P}_{\mathbf{2}}(\mathbf{4 \%})$ & $\mathbf{P}_{\mathbf{3}}(\mathbf{6 \%})$ \\
$\mathbf{M}_{\mathbf{0}}$ (Kontrol) & $4,24 \mathrm{~A} \mathrm{a}$ & $4,36 \mathrm{~A} \mathrm{a}$ & $4,03 \mathrm{~A} \mathrm{a}$ & $4,35 \mathrm{~A} \mathrm{a}$ \\
$\mathbf{M}_{\mathbf{1}}$ (10 g/tanaman) & $4,35 \mathrm{~A} \mathrm{a}$ & $3,90 \mathrm{~A} \mathrm{a}$ & $4,51 \mathrm{~B} \mathrm{a}$ & $4,48 \mathrm{~A} \mathrm{a}$
\end{tabular}

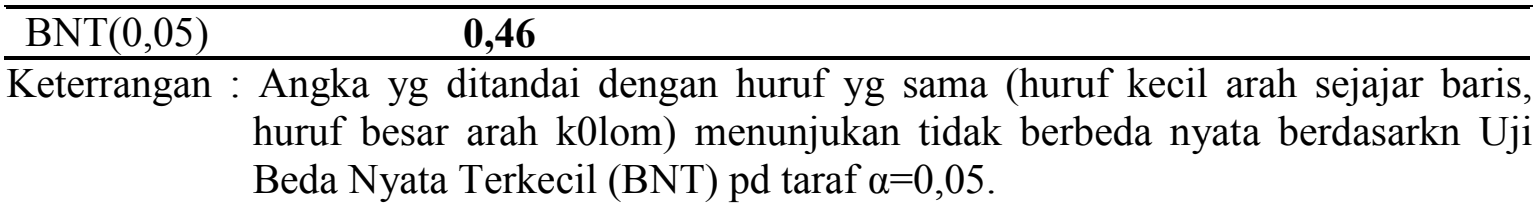

Tabel 2. Menunjukkan bahwa jumlah daun yang lebih banyak dijumpai pada kombinasi perlakuan $\mathrm{M}_{1} \mathrm{P}_{2}$ yaitu 4,51 yang berbeda nyata dengan perlakuan lainnya, sedangkan jumlah daun terendah dijumpai pada kombinasi perlakuan $\mathrm{M}_{1} \mathrm{P}_{1}$ yaitu 3,90. 


\section{Pembahasan}

\section{Pengaruh Pemberian Mikoriza terhadap Pertumbuhan Bibit Kopi}

Pemberian mikoriza berpengaruh tidak nyata terhadap semua parmeter (tinggi tanaman, jumlah daun, diaemeter pangkal batang, panjang akar, berat berangkasan basah dan berat berangkasan kering) yang diamati pada umur 30, 60 dan 90 HSPT. Hal ini diduga karena takaran pemberian mikoriza sangat sedikit didukung dengan hasil penelitian Lia et al., (2018) menyatakan bahwa FMA dengan takaran 40 sampai $50 \mathrm{~g} /$ tanaman dapat diaplikasikan pada pembibitan kopi arabika dan pemberian dosis inokulasi Fungi Mikorriza Akar dengan dosis $40 \mathrm{~g} /$ tanaman sampai $50 \mathrm{~g} /$ tanama dapat memerikan pengaruh yang paling baik terhadap tinggi tanaman dan berat kering tanaman.

Pemberian mikoriza dengan dosis $10 \mathrm{~g}$ /tanaman diduga belum mampu membantu penyerapan unsur hara untuk pertumbuhan tanaman, sehingga tidak berpengaruh terhadap semua parameter pengamatan.

Merujuk pada pernyataan Syafruddin et al., (2016) menjelaskan bahwa faktor lingkungan dapat memengaruhi perkembangan mikoriza dalam menginfeksi akar tanaman diantaranya seperti bahan organik tanah, ketersediaan hara, kadar air tanah, $\mathrm{pH}$, suhu, intensitas cahaya, logam brat dan fungisida.

\section{Pengaruh Konsentrasi Pupuk Organik Cair Limbah Kulit Pisang Pada Bibit Kopi}

Hasil penelitian menyatakan bahwa konsentrasi pupuk organik cair limbah kulit pisang berpengaruh nyata terhadap parmeter tinggi tanaman umur 60 HSPT, namun tidak berpengaruh nyata pada umur 30 dan 90 HSPT. Perlakuan terbaik dijumpai pada perlakuan $\mathrm{P}_{2}(4 \%)$ dengan rerata tinggi $4,22 \mathrm{~cm}$ yang berbeda nyata dengan pelakuan $\mathrm{P}_{0}$ (kontrol), $\mathrm{P}_{1}$ $(2 \%)$ dan $\mathrm{P}_{3}(6 \%)$. Konsentrasi $4 \%$, unsur hara pada pupuk organik limbah kulit pisang mampu mencukupi kebutuhan tanaman, salah satu unsur hara yang terkandung pada kulit pisang adalah nitrogen. Nitrogen pada tanaman berfungsi untuk merangsang pertumbhan secara kesluruhan, khususnya pada batang tanaman (Marviana et al., 2014). Hal ini sependapat dengan Novizan (2002), menjelaskan bahwa unsur hara yang dibutuhkan tanaman tersedia dalam jumlah yang cukup, untuk meningkatkan pertumbuhan tanaman. Didukung oleh Harjadi (2002), memaparkan bahwa penambahan unsur hara dari luar seperti pupuk dapat mempengaruhi petumbuhan tanaman, tanaman akan tumbuh baik jika unsur hara tersedia dan terpenuhi. Efisiensi pemupukan akan bagus dicapai apabila pupuk yang diberikn sesuai kebutuhan tanaman.

\section{Interaksi pemberian mikoriza dengan konsentrasi pupuk organik cair limbah kulit pisang tehadap pertumbuhan bibit kopi}

Hasil Uji F pd analisis ragam menunjukan bahwa terdapt interaksi yang berbeda tidak nyata antara pemberian mikoriza dan konsntrasi pupuk ogranik cair limbah kulit pisang terhadap parameter jumlah daun umur 30 HSPT pada pertumbuhan bibit kopi arabika. Hal ini dikarenakan pertumbuhan kopi arabika yang berpengaruh nyata akibat pemberian mikoriza pada taraf yang berbeda dipengaruhi oleh konsentrasi pupuk organik cair limbah kulit pisang begitu juga dengan dengan perlakuan konsentrasi pupuk organik cair limbah kulit pisang dipengaruhi oleh pemberian mikoriza. Didukung dengan Setiadi (1989), menyatakan bahwa persaingan antar mikoriza dan tanaman inang untuk mendapatkan energi karbohdrat, sehingga kedua faktor antara mikoriza dan pupuk organik cair limbah kulit pisang saling mendukung pertumbuhan bibit kopi arabika. 


\section{KESIMPULAN}

Pemberian mikoriza dengan dosis $10 \mathrm{~g} /$ tanaman berpengaruh tidak nyata terhadap semua parameter pertumbuhan bibit kopi pada umur 30, 60 dan 90 HSPT. Pemberian pupuk organik cair limbah kulit pisang berpengaruh nyata terhadap paremeter tinggi tanaman bibit kopi arabika umur 60 HSPT, namun berpengaruh tidak nyata terhadap tinggi tanaman 30 dan 90 HSPT. Konsentrasi pupuk organik cair limbah kulit pisang yang tepat terhadap petumbuhan bibit kopi dijumpai pada perlakuan $4 \%$. Terdapat interaksi antara pemberian mikoriza $10 \mathrm{~g} /$ tanaman dan konsentrasi pupuk organik cair limbah kulit pisang $4 \%$ terhadap petumbuhan bibit kopi.

Hasil penelitian memperlihatkan bahwa perlu dilakukan penelitian untuk lebih lanjut dengan menambah dosis mikoriza pada bibit kopi untuk meningkatkan produktivitas tanaman kopi.

\section{DAFTAR PUSTAKA}

Andrad, S. A. L, Mazzafera, P., Schiavinato, M. A., dan Silveira A. P. D. 2009. Review of arbuscular mycorrhizal association in coffee. Journal of Agricultural Science, $147,105-115$.

BPS [ Badan Pusat Statistik], 2016. Survei Sosial Ekonomi Nasional maret 2016.

Djodi, H, S. Sufardi, Syakur. 2013. Limbah kopi, EM-4 dan mikoriza untuk meningkatkan kualitas tanah dan pertumbuhan bibit kopi arabika Gayo-1 (Coffea arabica L.) Jurnal Manajemen sumber daya lahan. (3) 1.421-429.

Fadhlan. Rd, Irsal. Ginting. J. 2015. Respons pertumbuhan bibit kopi robusta (Coffea robusta L.) terhadap berbagai media tanam dan pupuk organik cair. Jurnal Agroekoteknologi FP USU. 5 (3) .678-684.

Hakim, A. M. 2009. Asupan nitrogen dan pupuk organik cair terhadap hasil dan kadar vitamin C kelopak bunga rosela (Hibiscus sabdariffa L.) , Skripsi Universitas Sebelas Maret, Surakarta.

Harjadi, S. S. 2002. Pengantar Agronomi. Gramedia. Jakarta.

Hulupi, R. 1999. Komposisi klon-klon kopi Robusta yang sesuai untuk tipe iklim basah, Warta Penelitian dan Pengembangan Pertanian, vol 21 No. 6, 6-7.

Karnilawati, Sufardi dan Syakur. 2013. Phosfat Tersedia, serapannya serta pertumbuhan jagung (Zea mays) akibat amelioran dan mikoriza pada andisol. Jurnal Manajemen Sumber Daya Lahan, 2(3), 231-239.

Lia, S. dan Taryana. Y. 2018. Pengaruh pemberian takaran fungi mikoriza arbuskular (FMA) terhadap pertumbuhan bibit kopi arabika (Coffea arabica L.). Jurnal Agro 5 (1). 
Madjid, A. 2009. Dasar-dasar ilmu tana. Bahan ajar online, Fakultas Pertanian Unri dan Program Studi Ilmu Tanaman, Program Magister (S2), Program Pascasarjana, Universitas Sriwijaya. Palembang. Propinsi Sumatra Selatan. Indonesia.

Mahdi, S. 2012. Viabilitas dan vigor bibit cabai (Capsicum annum L.) Akibat perbedaan cara aplikasi dan dosis mikoriza. Fakultas pertanian unsyiah. Banda aceh.

Marviana, D. D. dan Utami, L. B. 2014. Respon pertumbuhan tanaman terung (Solanum melogena. L.) terhadap pemberian kompos berbahan dasar tongkol jagung dan kotoran kambing sebagai materi pelajaran biologi versi kurikulum 2013. Jurnal Penelitian Mahasiswa Pendidikan Biologi, 1(1), 161-166.

Nasrullah, Nurhayati dan A. Marliah. 2015. Pengaruh dosis pupuk NPK (16:16:16) dan mikoriza terhadap pertumbuhan bibit kakao (Theobroma cacao L.) pada media tumbuh subsoil. Jurnal Agrium 12(2) : 56-64.

Nasution, Mawarni, Meriani. 2014. Aplikasi pupuk organik padat dan cair dari kulit pisang kepok untuk pertumbuhan dan produksi tanaman sawi (Brassica juncea L). Jurnal Agroteknologi Universitas Sumatra Utara. Vol 2 (3): 1029-1037.

Novizan. 2002. Petunjuk Pemupukan yang Efektif. Agromedia Pustaka. Jakarta.

Nurhakim, Y. Iman dan Rahayu, S. 2014. Perkebunan Kopi Skala Kecil Cepat Panen. Infra Pustaka. Depok.

Nyakpa, Y. M., A. M. Lubis, M. A. Pulung., A. G. Amrah., A. Munawar., G. B. Hong dan N. Hakim. 1998. Kesuburan Tanah. Universitas Lampung. Lampung.

Pranata, A. S. 2004. Pupuk Organik Cair Aplikasi dan Manfaatnya. Agromedia Pustaka. Jakarta.

Priangga, R., Suwarno \& Hidayat, N. 2013. Pengaruh level pupuk organik cair terhadap produksi bahan kering dan imbangan daun-batang rumput gajah defeliosi keempat. Jurnal ilmiah peternakan, 1 (1), 365-373.

Rambitan, V. M. M. dan Sari, M. P. 2013. Pengaruh pupuk kompos kulit pisang kepok (Musa paradisiaca L.) terhadap pertumbuhan dan hasil tanaman kacang tanah (Aracis hifogeal L). sebagai penunjang praktikum fisiologi Tumbuhan. Jurnal Education Biologi Tropika, 1(1), 1-60.

Santi, L. P. dan D. H. Goenadi. 2008. Pupuk Organo-kimia untuk Pemupukan Bibit Kelapa Sawit. Balai Penelitian Bioteknologi Perkebunan Indonesia. Bogor.

Setiadi, Y. 1989. Pemanfaatan mikroorganisme dalam kehutanan (p.103). Bogor; Pusat Antar Universitas Bioteknologi IPB-Lernbaga Sumberdaya Informasi IPB.

Siboro, E. S., E. dan Herlina. 2013. Pembuatan pupuk cair dan biogas dari campuran limbah sayuran. Jurnal Teknik kimia, 2(3), 40-43. 
Syafruddin S., S, Syakur dan T, Arabia. 2016. Propogation techniques of mycorrhizal biofertiliser with different types of mycorrhizal inoculant and host plant in Entisol Aceh.Int J. Agric. Res, 11 (2) : 69-76. 